\title{
Reduced Use of Fossil Fuels can Reduce Supply of Critical Resources
}

\author{
André Månberger ${ }^{1}$ (1) \\ Received: 4 February 2021 / Revised: 21 April 2021 / Accepted: 13 May 2021 / Published online: 24 May 2021 \\ (c) The Author(s) 2021
}

\begin{abstract}
Previous research has identified that climate change mitigation policies could increase demand for resources perceived as critical, because these are used in many renewable energy technologies. This study assesses how reducing the extraction and use of fossil fuels could affect the supply of (i) elements jointly produced with fossil fuels and (ii) elements jointly produced with a host that is currently mainly used in fossil fuel supply chains. Several critical resources are identified for which supply potential from current sources is likely to decline. Some of these, e.g. germanium and vanadium, have uses in low-carbon energy systems. Renewable energy transitions can thus simultaneously increase demand and reduce supply of critical elements. The problem is greatest for technology groups in which by-products are more difficult to recycle than the host. Photovoltaic cell technology stands out as one such group. Phasing out fossil fuels has the potential to reduce both the supply potential (i.e. primary flow) and recoverable resources (i.e. stock) of materials involved in such technology groups. Further studies could examine possibilities to increase recovery rates, extract jointly produced resources independently of hosts and how the geographical distribution of by-product supply sources might change if fossil fuel extraction is scaled back.
\end{abstract}

Keywords By-product $\cdot$ Climate change mitigation $\cdot$ Critical resource $\cdot$ Energy transition $\cdot$ Joint production

\section{Highlights}

- Renewable energy technologies use critical resources (CRs)

- Some CRs are produced as part of the production and use of fossil fuels

- Mitigating climate change can simultaneously reduce supply and increase demand of CRs

- Potential flows, reserves, and recoverable resources require downward revision

\section{Introduction}

It is widely acknowledged that mitigating climate change will necessitate the reduction of the use of fossil fuels and the increased use of renewable energy (GEA 2012; IEA 2017). Previous research has examined how the production

André Månberger

Andre.Manberger@miljo.lth.se

1 Environmental and Energy Systems Studies, Lund University, P.O. Box 118, 22100 Lund, Sweden of renewable energy affects demand for metals perceived as critical (Tokimatsu et al. 2018), metal supply bottlenecks that can constrain a low-carbon energy transition (Valero et al. 2018), to what extent recycling, improved material efficiency and substitutes can reduce demand for virgin resources (Månberger and Stenqvist 2018) and the geographical distribution of metals used in renewable energy systems (Church and Crawford 2018).

Both supply- and demand-side factors contribute to making some metals critical (Graedel and Reck 2016; Schrijvers et al. 2020), for example: whether production sites or reserves of the material are geographically concentrated; whether the metal is produced jointly with a host resource; whether substitutes are inferior or non-existent; or whether one or several applications of the metal have high economic, social, or military significance. Previous research has shown that energy transitions induced by climate mitigation objectives will increase total metal demand, since renewable energy is more material intensive than fossil energy (Watari et al. 2019).

By-products are recovered from host resources after these have been extracted. They are often not profitable to extract on their own. As a result of joint resource production, host resource supply (and thus host demand for it) will affect 
the supply potential of by-product resources that are recovered from the host. Nassar et al. (2015) identified ten host resources (silicon, platinum, gold, aluminium, titanium, iron, nickel, copper, zinc, and lead) on which supplies of byproducts, such as indium, germanium, and gallium, depend. Although the production of these two groups of metals is connected, they are not subject to identical market pressures. By-products typically fetch a higher market price than the host (or "carrier") per weight, but the total economic value for the producer is much higher for the host due to the higher volume (Fu et al. 2018). As a result, the supply of byproduct metals is less responsive to price increases than is the supply of host metals, i.e. lower price elasticity (Jordan 2018; Redlinger and Eggert 2016). For example, Fu et al. (2018) estimated the long-term supply elasticity for three byproducts (indium, germanium, and selenium) to be between 0.02 and 0.1 . The authors caution that these estimates are uncertain for several reasons: the difficulty of anticipating market prices; strategic stockpiling by states; and states paying above the market price for resources in exchange for guaranteed long-term supply contracts. It should be noted that a continuum exists for the relative value of the host and the resource that is jointly produced with it (Fizaine 2013). The economic literature refers to jointly produced resources as co-products when the relative values of the resources are similar, and as by-products when the difference is large. One example of a by-product is gallium, which is recovered from aluminium (bauxite). Its market price would have to increase more than 20-fold for gallium to have a similar value as the aluminium it is recovered from (Frenzel et al. 2016).

In short, host resource supply influences the supply potential for by-products when the by-product is not economic to produce on its own. Watari et al. (2020) identified that research of future resource supply chains are often inconsistent, because the linkages between host and by-products are not factored in when material flows are analysed. In theory, the supply of a given by-product will fall short of demand if (i) demand for the by-product grows more rapidly than demand for the host; or (ii) primary supply of the host declines. Previous studies have focused on the former relation and argued that an increase in the production of wind power (Nassar et al. 2016) and solar photovoltaics (Elshkaki and Graedel 2015) may strain the supply of necessary byproduct materials. However, for at least some resources, it may not be necessary to increase production of the host material in order to increase by-product production. As it stands, not all metal refineries are equipped with by-product recovery technologies; if they were fitted with these, more by-product could be produced relative to the volume of host product (Fizaine 2013; Frenzel et al. 2017). Supply for indium could be tripled in this way, while supply for gallium and germanium could potentially be increased tenfold (Frenzel et al. 2017).
Future by-product supply potential is sensitive to how the primary supply of the host will develop, but research on this topic is scarce. Some studies have noted that technological disruptions that reduce host demand will affect the supply of both host and co- or by-product resources (Løvik et al. 2016; Sprecher et al. 2017). However, no study to date has examined whether and how mitigating climate change might reduce the demand and supply of non-fossil resources, and which resources could be affected. These are the focal issues of the present study. Of particular interest are resources for which climate change mitigation is likely to both reduce supply and increase demand.

This study's main novel contribution is that it identifies which jointly produced resources may be subject to a decline in supply (flow) and/or availability (stock) if fossil fuel use is reduced in the future (Sects. Resources Produced Jointly with Fossil Resources and Jointly Produced Elements from Elements Used in the Fossil Energy System). This study also identifies end-use sectors that are exposed to the risk of reduced supply of elements jointly produced from the fossil fuel supply chain (Sect. Discussion). Metals used in current solar photovoltaics can become scarcer as a result of climate mitigation measures, which simultaneously reduce supply and increase demand for these metals. Overall, this study contributes to the literature on joint resource production, critical materials, and to the growing research field of the materiality of energy transitions.

\section{Method}

This paper starts by assessing four elements (germanium, helium, sulphur, and vanadium) future supply potential (Sect. Resources Produced Jointly with Fossil Resources). These elements are being supplied, entirely or in part, by a process or processes in the fossil fuel supply chain. In other words, these elements are jointly produced with fossil fuels. This study then identifies elements for which a majority of the demand is attributed to the extraction or use of fossil energy, using data on different elements' primary applications found in the literature (Fortier et al. 2018; Schulz et al. 2017; UNEP 2011; USGS 2019). Three steps in the fossil fuel supply chain are analysed: extraction, refining, and final use (see Fig. 1). Three individual elements (barite, lead, and rhenium) and one group (the platinum-group elements, PGE) are identified as being used primarily in fossil supply chains (see Sect. Elements Primarily Used in Fossil Energy Systems Today). Some of these elements are hosts to other elements, which means that their production affects the supply of elements that are jointly produced with them. Section Jointly Produced Elements from Elements Used in the Fossil Energy System 
Fig. 1 Illustration of three steps in the fossil fuel supply chain (second line), elements recovered from these steps (top line, Sect. Resources Produced Jointly with Fossil Resources in the article), elements used in the different steps (third line, Sect. Elements Primarily Used in Fossil Energy Systems Today), and elements jointly produced with these (bottom line, Sect. Jointly Produced Elements from Elements Used in the Fossil Energy System)

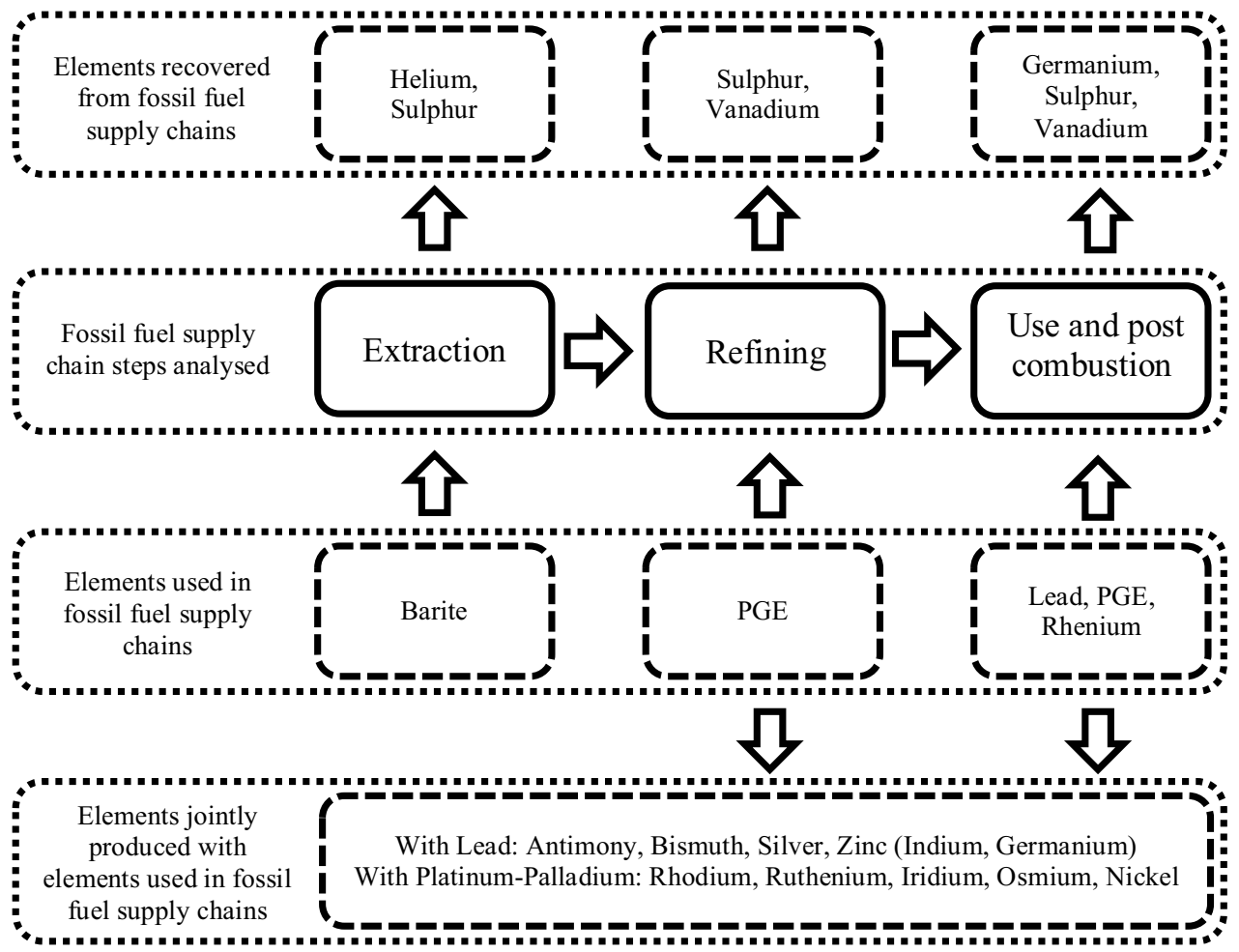

explores which elements are jointly produced with hosts that are primarily used in in the fossil energy system.

This paper divides jointly produced elements into two groups: co-products, which have similar values for the producer and are often separated at an early stage (e.g. during concentration), and by-products, which tend to be produced in smaller quantities and require more processing to separate (e.g. at the refining, smelting, or postcombustion stages). The distinction is, therefore, a matter of the relevant ores' geological properties, the techniques used to extract and refine metals from them and relative market prices.

The supply potentials of Germanium, Helium, and Sulphur recovered from fossil fuels were calculated following Frenzel et al. (2017):

$\sum_{i=1}^{N} m_{i} \cdot x_{i} \cdot R\left(x_{i}, x_{\text {cut }- \text { off }}^{d}\right)$,

where $\mathrm{N}$ is the number of recoverable sources, $m_{\mathrm{i}}$ is the mass (or for natural gas volume) of the ith source, $x_{\mathrm{i}}$ is the by-product concentration in the $i$ th source, and $R\left(x_{i}, x^{d}{ }_{\text {cut-off }}\right)$ is the recovery rate, i.e. the share of the by-product that can be recovered depending on the cut-off grade of the waste stream $d$. Data for fossil fuel by-product contents and recovery rates are adopted from previous studies (Frenzel et al. 2013, 2017; Olafsdottir and Sverdrup 2020; Oliver et al. 1984; Rappold and Lackner 2010; Speight 2019; Zartmann et al. 1961), see also supplementary material.
Supply potential scenarios up to 2040 were developed by multiplying supply potentials for different fossil resources with two energy scenarios developed by IEA (2020). The two scenarios are here referred to as business as usual (BAU) and sustainable development (SD). These are widely used in academia, government agencies, and businesses for research and long-term energy planning.

The supply scenarios were compared with current end use, using data from USGS (2020a). Two supply risk metrics are developed and used in Sect. Resources Produced Jointly with Fossil Resources to measure (i) how the potential supply-to-use ratio changes, if end use stays the same, and (ii) the maximum compounded annual growth rate (CAGR) of primary use from 2020 to 2040 . A low, or negative, CAGR indicates that supply scarcity may increase. Demand growth greater than this rate would have to be meet from other sources (e.g. recycling, recovered from other sources or primary production entailing higher production cost).

Data on mining output and geo-economic datasets on content in ore deposits (Mudd et al. 2017b, 2018; Nassar et al. 2015) are analysed in Sects. Resources Produced Jointly with Fossil Resources and Jointly Produced Elements from Elements Used in the Fossil Energy System to identify co- and by-products associated with the host, and to quantify how large a share of the total value these jointly produced resources make up, compared to the host, for different ore bodies and mines. This is combined with estimates of the supply share that is jointly produced from the respective hosts (Nassar et al. 2015) to get a proxy of how supply 
Fig. 2 Potential germanium supply ( $t / y$ ) up to 2040 for sustainable development (left) and business-as-usual (right) scenarios from coal with high ( $>200 \mathrm{ppm})$ and moderate $(8-200 \mathrm{ppm})$ germanium concentration. Current levels used for supply potential from zinc (grey) and demand (blackdashed line)

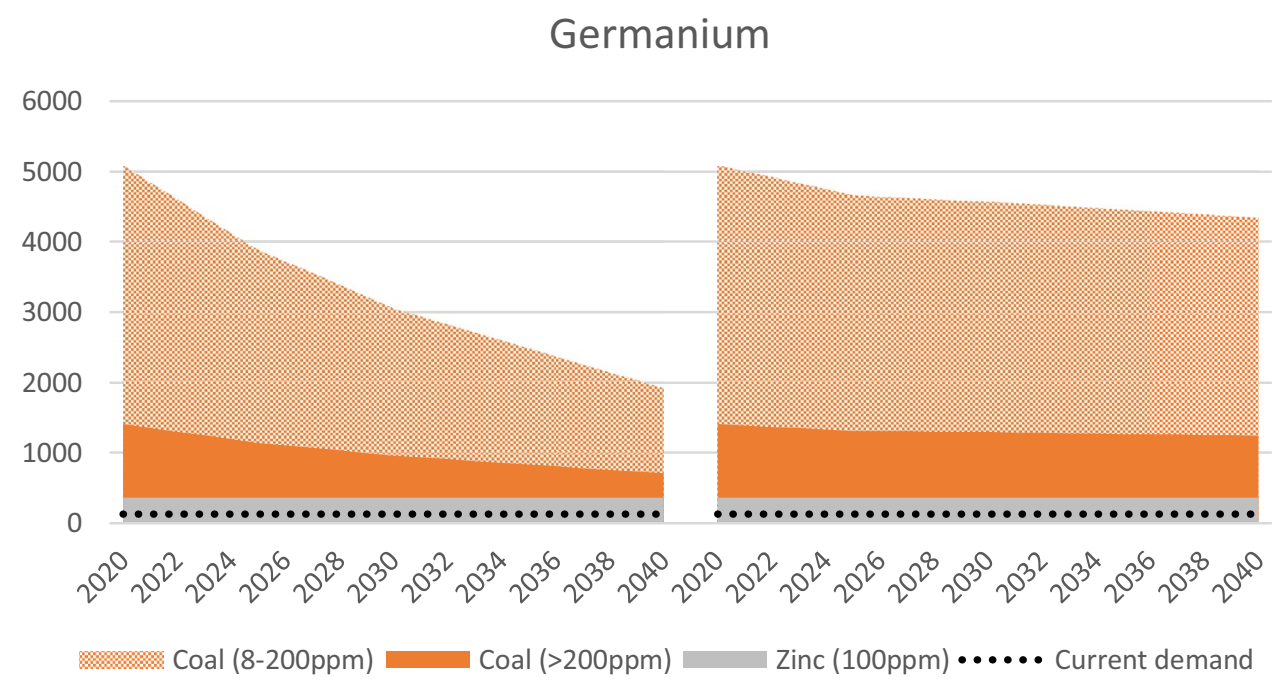

and availability of co- and by-products could be affected by lower host supply. The datasets that were used have been published previously for other purposes (as supplementary materials to the cited sources), the implications of reduced supply of fossil resources for critical resource supply have not been published before.

Section Discussion discusses the implications for the use of the resources identified in the previous sections and future research areas. Data on final use of elements are gathered from the literature (Fortier et al. 2018; Schulz et al. 2017; UNEP 2011; USGS 2019) and used to identify sectors exposed to increased scarcity after considering available substitutes.

\section{Resources Produced Jointly with Fossil Resources}

This section identifies and analyses how resources are jointly produced with fossil fuels, and the extent to which these resources are, or could be, produced independently. Supply scenarios are developed for the three resources (germanium, helium, and sulphur) that have the highest share of their respective supply potential from fossil fuels.

\section{Germanium}

Nassar et al. (2015) estimate that about $40 \%$ of germanium is produced from coal fly ash. The coal is first mined and combusted so that the germanium concentration increases. The remainder of the primary germanium production is recovered from the leaching of zinc. However, coal makes up the vast majority (89-94\% depending on cut-off grade) of potential supply (Frenzel et al. 2013). Based on estimates for cut-off grades, recovery rates, and germanium content from Frenzel et al. (2013), the future supply potential is reduced by more than half in 2040 in the SD scenario compared to BAU, see Fig. 2.

The potential supply-to-use ratio is currently 39 (using $8 \mathrm{ppm}$ as cut-off grade for coal). It declines to 33 in the BAU scenario and 18 in the SD scenario. Up until 2040, it is possible for primary demand to increase from 91 ton/y to about 1900 or $16.5 \%$ year in the SD scenario. For the higher cut-off grade (200 ppm), the supply-to-use fraction drops to 5 in the SD scenario, enabling primary supply to grow by $11 \% / y e a r$. It should be remembered that such growth rates are theoretical. The historic long-term supply elasticity for germanium is estimated to be 0.02 (Fu et al. 2018) indicating a slow supply response to higher prices. In the long term, the prospects for carbon capture will affect coals prospect in a low-carbon energy system and, thus, the potential germanium supply.

Germanium is not recovered from coal comes from sulphidic zinc ore. Future primary zinc supply is, thus, of importance for the supply potential. Moreover, zinc is typically extracted together with lead. Lower primary lead demand could, thus, also affect the profitability of zinc and, thus, also germanium extraction that does not originate from coal.

\section{Helium}

Current helium supply depends entirely on fossil fuel production. Helium is the second most common element in the universe and is available in the earth's atmosphere, but lowcost production requires a higher concentration, which is found in some conventional natural gas fields. Alongside methane, these fields trap helium released by decaying thorium and other radioactive materials. Shale formations do not trap helium and are, therefore, not a viable helium source (Nuttall et al. 2012). Maximum potential helium production is, therefore, assumed to be a function of conventional gas 


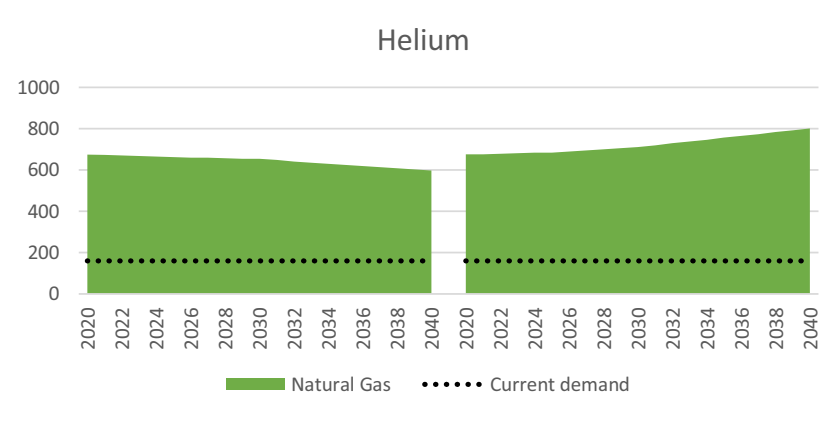

Fig. 3 Potential helium supply $(\mathrm{mcm} / \mathrm{y})$ up to 2040 for sustainable development (left) and business-as-usual (right) scenarios from natural gas. Current level is used for demand (black-dashed line) (Color figure online)

production. Helium can be separated from natural gas when the natural gas is processed or liquefied (Anderson 2017). ${ }^{1}$ A small share of global helium supply also originates from the $\mathrm{CO}_{2}$ stream used in enhanced oil recovery.

Using assumptions for helium content in natural gas, cutoff grade $(0.8 \%)$ and recovery rate $(50 \%)$ from previous studies (Olafsdottir and Sverdrup 2020; Zartmann et al. 1961) show that potential helium supply declines in a sustainable development scenario, see Fig. 3. It should be noted that liquefaction make hydrogen from gas fields with lower concentration profitable to recover than what is possible at the processing stage, but this possibility is not explored further in this study.

The potential supply-to-use ratio is currently 4.2. It declines to 3.7 in the SD scenario and grows to 5.0 in the BAU scenario. Up until 2040, it is possible for primary demand to increase by $6 \% / y e a r$ in the SD scenario and $9 \% /$ year in the BAU scenario.

It is possible to produce helium independently of fossil fuel extraction, but the cost of doing so is significantly higher. Since this is not currently done, production cost curves remain uncertain. A handful of geological spots in North America and Tanzania have been identified, which may contain sufficiently high helium concentration to enable primary extraction, but production at these locations is not commercial (Danabalan 2017; Edison 2017). Another possibility is air separation, but the energy cost of doing so makes this uneconomical at the moment. Some estimates indicate that air-separated helium would cost 60-100 times more than crude helium (similar to the cost of liquid neon separated from air), but such estimates are sensitive to assumptions about energy cost and the allocation of capital cost (Clarke and Clare 2012). Clarke and Clare (2012) estimate

\footnotetext{
${ }^{1}$ Several other gases such as ethane and propane are also natural gas by-products, but these are not included here as they are organic compounds composed of carbon and hydrogen, not unique elements.
}

that helium could be separated from air at a little less than triple the cost of extracting it from crude helium if existing cryogenic plants were refitted. However, the potential is limited to about $1-2 \%$ of current global helium production, as this corresponds to air separation production capacity (National_Research_Council 2000).

\section{Sulphur}

About $60 \%$ to $70 \%$ of sulphur supply is recovered from fossil fuels (USGS 2020b). The two largest recovered sources are petroleum refining and natural gas processing. The flow of sulphur embedded in coal is higher than all other sources combined but virtually all of this ends up as waste as the recovery cost is higher than for other sources. Metal smelting of sulphidic minerals (e.g. the copper mineral chalcocite) is another host source that make up somewhere between $22 \%$ and $30 \%$, this also includes a small share derived from coke processing (USGS 2020b).

Potential sulphur supply declines in both the SD scenario and BAU scenario, see Fig. 4. The potential supply-to-use ratio is currently 3.1. It declines to 1.7 in the SD scenario and grows to 3.0 in the BAU scenario. Up until 2040, it is possible for primary demand to increase by $3 \% / y e a r$ in the SD scenario and 5\%/year in the BAU scenario. Removing coal as a supply source reduces the supply-to-use ratios to 1.2 in the SD scenario and 1.6 in the BAU scenario.

Sulphur is the $16^{\text {th }}$ most abundant element on earth, and it is found in concentration sufficient to enable primary production, in sulphides and dissolved in oceans (Maier 2015). Sulphur can be mined or extracted by steam injection, depending on geological conditions. Primary production was used to dominate supply but was outpriced in the 1990's and presently makes up less than $10 \%$ of the supply (USGS 2020b). Sulphur deposits are not depleted. The reason was increased recovery from fossil fuels that provided supply at lower cost. Currently, a majority of sulphur is used for producing phosphorous fertilizers, as a pesticide and as a soil nutrient (Wagenfeld et al. 2019). Unless this loop is closed, a low-carbon energy transition may incentivise expanded primary sulphur production.

\section{Vanadium}

About $10 \%$ of global vanadium production is recovered from fossil fuels, most of this separated from heavy oils when they are refined (Schulz et al. 2017). The share could be much higher given that a minority of all vanadium is presently recovered, and then only from fly ash post-combustion, petroleum residues, and spent refinery catalysts. Oil's vanadium content differs widely but is highest in heavy oils, in which the average vanadium content is estimated to be about 
Fig. 4 Potential sulphur supply (Gt/y) up to 2040 for sustainable development (left) and business-as-usual (right) scenarios from natural gas (green), heavy oil (dashed blue), oil (blue), and coal (orange). Current levels used for supply potential from sulfidic ores (grey) and demand (black-dashed line) (Color figure online)

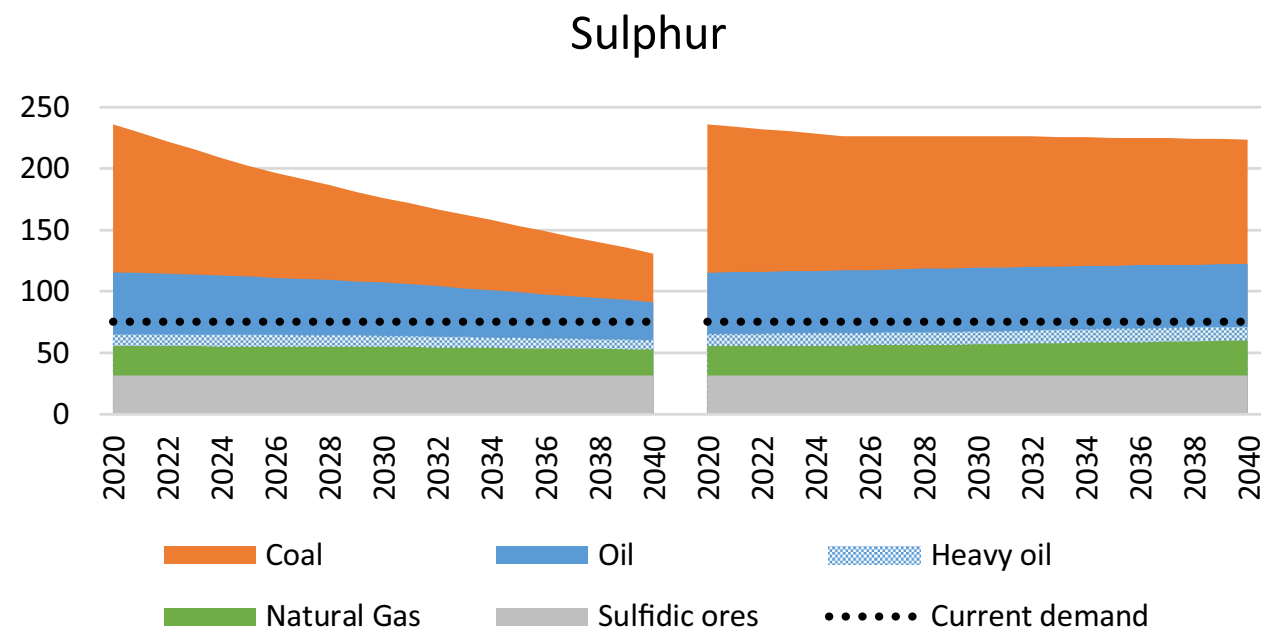

200ppmw. ${ }^{2}$ Vanadium not recovered at refineries becomes anthropogenic emissions, which is from oil alone amount to $60 \mathrm{kt}$ per year (Imtiaz et al. 2015). This flow is similar to the primary supply from mining, 73kt in 2018 (USGS 2019).

Most of the current vanadium supply ( $82 \%$ ) is a companion to another resource, of which iron makes up the highest share (62\%) (Nassar et al. 2015). Reduced production of heavy oil would, thus, have a minor impact on current global vanadium supply.

\section{Potential Resources Currently Not Exploited}

Coal and oil contain traces of metals that are presently not recovered but could be. The main prospective candidates are gallium and REE, but other elements have also been suggested as promising, such as lithium, beryllium, selenium, and antimony (Lin et al. 2018a, b). Frenzel et al. (2016) estimate that $1265 \mathrm{t} / \mathrm{y}$ of gallium could be recovered from brown and hard coal. ${ }^{3}$ This is about three times higher than the current primary production of 410 t/y (USGS 2019). Coal deposits have different REE contents, and a study from the US found that less than $10 \%$ had sufficiently high concentration to be viable potential sources, given current technology and prices (Lin et al. 2018a). A study from China identified a coal seam that could supply $12 \mathrm{kt}$ of rare-earth oxides annually (Seredin and Dai 2012), corresponding to 7\% of global production in 2018 (USGS 2019).

\footnotetext{
2 Average vanadium content in Canadian heavy oil is 200ppmw (Stantec 2018). The variance is large, e.g. Russian heavy oil range from 90 to 1650 ppmw (Yakubov et al. 2017).

3 The authors provide an uncertainty range from 590 to $2645 \mathrm{t} / \mathrm{y}$.
}

\section{Elements Primarily Used in Fossil Energy Systems Today}

\section{Barite}

The main application of barite is as a weighting agent when drilling for oil and gas, although the share used for this purpose has declined from 88\% in 2003 to $70 \%$ in 2018 (Bonel 2005; The_Barytes_Association 2019). Barite prevents unwanted blowouts that would otherwise occur due to high reservoir pressure, and it also cools the drill bit. Barite is not recycled, and global demand, therefore, follows the rig count of the oil and gas industry's business cycle. Barite is also very dense, non-reactive, and non-magnetic. No particular use of barite in low-carbon energy systems has been identified, which could compensate for reduced demand from oil and gas drilling.

\section{Lead}

The main application of lead is in the Starter Lighting Ignition (SLI) batteries used in internal combustion engines. This makes up around 70\% of lead's use (UNEP 2011). An additional $15 \%$ is used in non-vehicle batteries, such as those in forklifts and back-up power systems, to provide an uninterruptible power supply (ILA 2012). There are many other applications, but most of these have seen a decline in demand due to the adoption of substitutes that are less toxic to humans and the environment. These include pigment, tin can sealant, cable isolation, pipe systems, octane enhancer, ammunition, radiation blocking, and solders. Lead-acid batteries could in principle also be replaced by other cathode and electrode materials, such as lithium-ion batteries (Ferg et al. 2019).

The recycling efficiency of batteries is close to $100 \%$, and secondary lead sources make up $60-66 \%$ of the total 
lead supply (Zhang et al. 2016). The share of metal that is recycled varies by region: in the USA, it is $>80 \%$, in Europe $>90 \%$, but only $44 \%$ in China (Sun et al. 2017; Zhang et al. 2016). China's domestic demand for lead has increased, but it would still be possible to reduce the primary supply by $30 \%$ and satisfy current demand if management efficiency was to improve (Sun et al. 2017).

Lead could in principle be used for energy storage in renewable energy systems. However, it is uncertain how this demand would compare with current demand from SLI batteries. Lead-acid batteries would have to compete with low-cost vanadium redox flow batteries, which have a much longer lifespan, and lithium-ion batteries, which have higher energy density and power, and a longer lifespan. Perovskite solar cells use lead, but the technology is currently not mature, and demand is likely to be low compared to current battery use as lead intensity in perovskite solar cells is low.

\section{Platinum-Group Elements}

There are six platinum-group elements (PGE): platinum $(\mathrm{Pt})$, palladium $(\mathrm{Pd})$, iridium $(\mathrm{Ir})$, osmium $(\mathrm{Os})$, rhodium $(\mathrm{Rh})$, and ruthenium $(\mathrm{Ru})$. The PGEs have many properties in common, such as the ability to catalyse chemical reactions. This means they can be substituted for one another as relative prices change. They are also often mined together (Gunn 2014). For these reasons, they are analysed here as a single group.

The main use of PGEs is in catalytic conversion, to reduce polluting emissions from vehicles. In total, $86 \%$ of palladium, $80 \%$ of rhodium, and $39 \%$ of platinum were used in catalytic conversion in internal combustion vehicles in 2018 (Cowley 2019). Systems to treat diesel emissions contain more platinum than palladium, due to the use of platinum in particle filters. Other applications for platinum include petroleum refineries (about $4 \%$ of demand), oxygen sensors in vehicle exhausts that control the air-fuel mixture in fuel injection systems, and as an alloy with iridium in spark plugs. The main non-fossil uses of platinum are jewellery (30\% of demand), investment bars and coins (1-8\% in the last years), and the industrial manufacture of glass and chemicals (25\%).

In non-fossil energy systems, PGEs can still be used in post-combustion pollution control for bioenergy generation and in bio-refineries. A potential new market is hydrogen fuel cells. Hydrogen vehicles use more platinum than diesel vehicles do for pollution control, but the metal intensity ( $\mathrm{g}$ $\mathrm{Pt} / \mathrm{kW}$ ) has declined over time and is expected to continue to do so (Månberger and Stenqvist 2018). Some manufacturers claim that, by early 2020 , their vehicles' fuel cells will only require the same amount of platinum as is currently used in diesel catalytic converters (Onstad 2019).
South Africa has more than $90 \%$ of PGE reserves and provides approximately $60 \%$ of primary supply (USGS 2019). PGEs are mined as hosts in South Africa and mainly as byproducts in nickel-copper-dominant ores in other countries (Gunn 2014). Palladium makes up 50\% of the PGE market, platinum 39\%, ruthenium 5\%, and rhodium 5\% (Cowley 2019). Data on osmium are lacking due to its low use.

\section{Rhenium}

The main application (83\%) of rhenium is as a super alloy that improves the heat resistance of turbine blades used mainly in the aerospace industry. An additional $10 \%$ is used in platinum catalysts in petroleum refineries (Schulz et al. 2017). Adding rhenium to the catalyser increases the yield of high octane fuel (Naumov 2007). Rhenium's thermoelectric property has led to a small share being used in electrical contacts. No particular application of rhenium in non-fossil energy systems has been identified. Aeroplanes that use renewable energy (e.g. biofuels or electrofuels) may be a source of future demand in a carbon-constrained world.

\section{Jointly Produced Elements from Elements Used in the Fossil Energy System}

Section Elements Primarily Used in Fossil Energy Systems Today identified that four groups of elements are today used primarily in the fossil energy system: barite, lead, platinumgroup elements, and rhenium. Two of these metals, lead and the PGE, are mined as hosts. This section analyses the elements jointly produced with these two. It is unclear if, and to what extent, demand for lead and PGE would be in a low-carbon energy future as new sources of demand may emerge (see Sect. Dynamic Assessments of Criticality and Geopolitics). The aim of this section is, therefore, to identify their co- and by-products rather than providing supply scenarios similar to Sect. Resources Produced Jointly with Fossil Resources.

\section{Lead co- and by-Products}

Lead sulphide (Galena, $\mathrm{PbS}$ ) is the ore mineral that most commercial lead mines extract from sediment-hosted $\mathrm{Pb}-\mathrm{Zn}$ deposits (Werner et al. 2017b). Mines that only extract lead are uncommon, because the ores usually consists of minerals rich in lead and zinc (and sometimes silver). Only in a small proportion of the mineral deposits containing lead, does the lead contribute more than $50 \%$ of their value (see supplement). Mining operations, therefore, typically extract both lead and zinc. Which of the two supplies the greater share of their revenue depends on local geological conditions, minerals targeted by the mine, and current market prices? 
The metals contained in the minerals can either be separated at an early stage (separating at the concentrate stage provides co-products) or later, during the smelting and refining process (providing by-products). This has implications for which metals become unprofitable to produce if demand for a host metal declines. If demand for primary lead declines, for example, then the production of metals separated during the smelting of primary lead will likely decline, whereas metals separated at an earlier stage may still be profitable to produce. The following two sections therefore analyse metals separated during lead refining and those found in minerals associated with lead ores, respectively. Reduced lead mining would directly reduce the supply of metals in the former category; it could also indirectly affect the supply of lead-co-products, if extraction of some mineral deposits becomes insufficiently profitable. It should be noted that some metals (e.g. silver and zinc) belong to both of these categories, but a majority of lead's co- and byproducts are in either one or the other. There are combined lead/zinc smelters, such as those used in the imperial smelting process, but these are not common.

\section{By-Products Separated During Lead Smelting or Refining (Bismuth, Antimony and Silver)}

The majority of global bismuth supply is produced as a byproduct from lead at lead-refining plants (Klochko 2016). The exact share is uncertain; Nassar et al. (2015) estimate it to have been $54 \%$ in $2008 .{ }^{4}$ The second most important source is from tungsten mining, in China and Vietnam, while most of the remainder comes from copper and tin refining (Krenev et al. 2015). Bolivia was home to the only primary bismuth mine that has existed, the Tasna Mine, but its output made up less than $0.5 \%$ of global primary production when it was operational (Ojebuoboh 1992).

Antimony is mainly produced as a by-product from lead. Nassar et al. (2015) estimate that, of total antimony production worldwide, $40 \%$ is a lead by-product and approximately $20 \%$ is the host product. Antimony produced from lead is separated during the lead smelting process. About $10 \%$ of global antimony demand is for use as an alloy in lead-acid batteries (Anderson 2019). Thus, reduced lead demand from SLI batteries would also reduce antimony demand.

$\mathrm{Pb}-\mathrm{Zn}$ ores make up the largest share $(36.5 \%)$ of silver production; the second largest source (29\%) is as the host (Nassar et al. 2015). A majority of the silver associated with $\mathrm{Pb}-\mathrm{Zn}$ is obtained from lead concentrate, because the

\footnotetext{
${ }^{4}$ The share from lead mining has declined over time. 30 years ago Campbell (1985) stated that all bismuth was associated with lead production. Reuter et al. (2005) estimated that $61 \%$ of bismuth is recovered from lead (using the Kroll-Betterton process) and an additional $18 \%$ from lead or copper anode slimes (using the Betts-process).
}

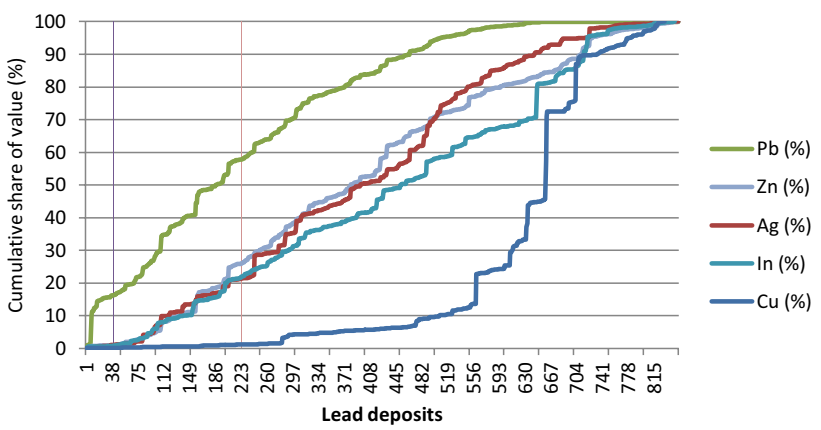

Fig. 5 Cumulative share of value from: lead, zinc, copper, silver, and indium for identified ore deposits that contain lead. Share of value from lead was used to arrange the data, i.e. deposits to the left get almost all of their value from lead and those to the right almost none. Vertical lines correspond to $50 \%$ and $20 \%$, respectively, of deposit value from lead content, i.e. deposits between the lines have $20-50 \%$ of their value from lead. Own calculations based on the 851 mineral lead-zinc deposits from the dataset published in Mudd et al. (2017b). Note: zinc and germanium have the same share, as the germanium content is assumed to be a function of zinc content

proportion of silver is much higher in galena than in zinc sulphide. Silver is removed from the lead bullion after smelting, using the Parkes process.

Galena contains small amounts of indium but the content is an order of magnitude lower than in sulphidic zinc ores, which has so far prohibited commercial production (Frenzel et al. 2017). Currently, more than $95 \%$ of indium is a byproduct of zinc refining (Werner et al. 2017a). Indium is, therefore, included as co-product (5.1.2). This is also the case for copper, of which $2 \%$ of the global production is associated with $\mathrm{Pb}-\mathrm{Zn}$ (Nassar et al. 2015). However, most of this is separated from lead at the concentration stage, with a small share separated during lead smelting.

\section{Co-products Found in Minerals Associated with Lead Ores (Zinc, Silver, Indium, Germanium, and Copper)}

Lead deposits usually also contains zinc, which in its turn has traces of germanium and indium that can be extracted at the refining stage (Mudd et al. 2017b). In addition to this, lead deposits sometimes contain commercial quantities of copper. Assuming ore deposits that obtain most of their value from their lead content would be affected if demand for lead is reduced, the content of other metals in lead-rich deposits is analysed here using a dataset found in Mudd et al. (2017b) (see Fig. 5). The dataset was complemented by the assumption that zinc ores contain $118 \mathrm{~g}$ indium per tonne of zinc where no data on indium content were available (assumption based on Mudd et al. (2017a)) and $175 \mathrm{~g}$ germanium per tonne of zinc (assumption based on Sprecher et al. (2017)). Zinc ores also contain a small amount of 
Fig. 6 Cumulative share of value from platinum, palladium, rhodium, ruthenium, Iridium, gold, nickel, copper, cobalt, and chromium, in mining output from mines that produce PGE. Share of value from the sum of PGEs was used to arrange the data in descending order, i.e. mines to the left get almost all of their revenue from PGEs and mines to the right get almost none of their revenue from PGEs. Vertical grey line corresponds to $50 \%$ value from PGEs. Based on dataset published in (Nassar et al. 2015)

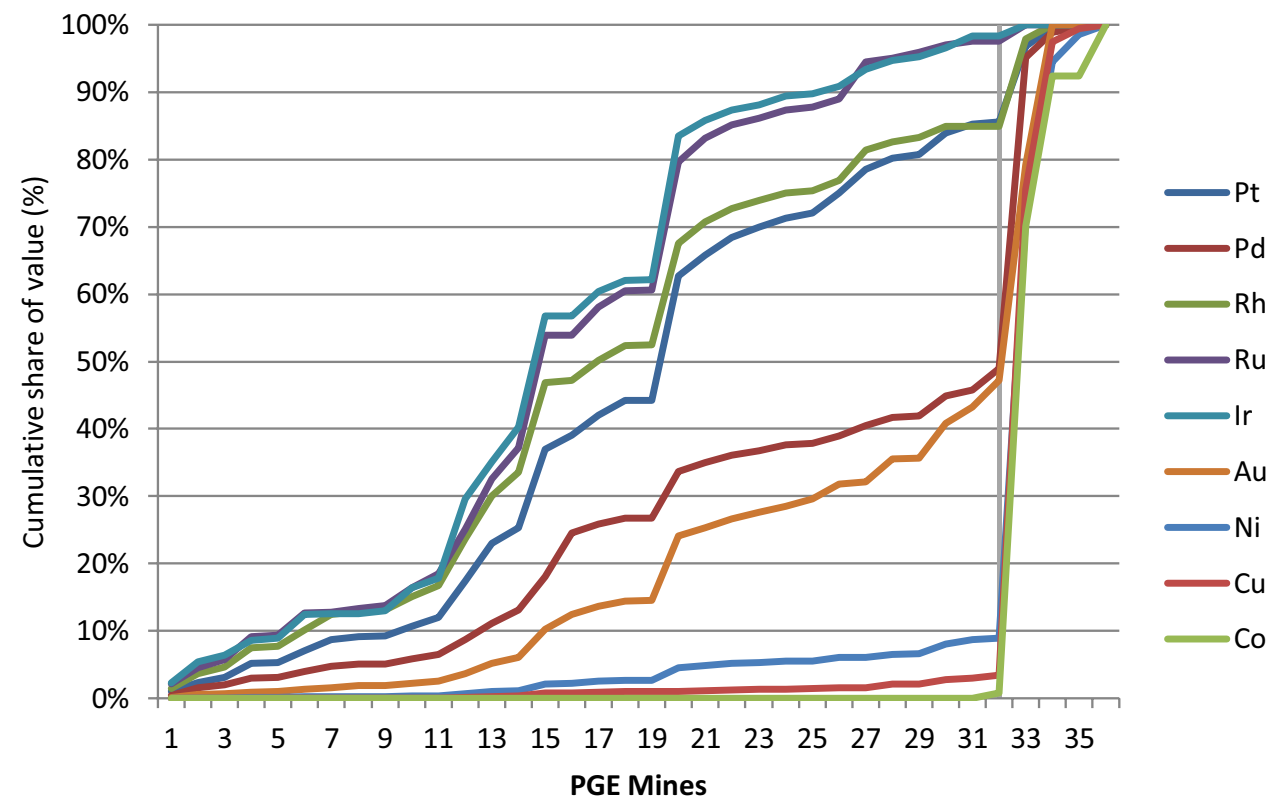

gallium, but this is not separated in any significant quantities (Nassar et al. 2015).

Ore deposits that obtain $20 \%$ or more of their value from their lead content make up $57.8 \%(130.72 \mathrm{Mt})$ of total $\mathrm{Pb}$ ore content in the dataset. These deposits are candidates for not being mined (or, where mines already exist, for these mines being closed down) should demand for virgin lead decline. These ores also contain $158.3 \mathrm{Mt}$ zinc $(25.9 \%$ of the zinc resource reported in the database), $178.7 \mathrm{kt}$ silver (as a point of reference, this is equivalent to $31.9 \%$ of the silver reserve in 2019, according to (USGS 2019)), $1.65 \mathrm{Mt}$ copper, and $107 \mathrm{t}$ gold. Content of other metals is not always reported, and quantifications are, therefore, less certain and understated. Based on reported figures, lead-rich deposits also contain small amounts of barium, nickel, cobalt, and tin.

Ore deposits that obtain $\geq 50 \%$ of their value from lead contain $36.65 \mathrm{Mt}$ lead (i.e. $16 \%$ of the all the lead in the dataset) and small amounts of other metals such as zinc (5.8Mt), silver (8.6Mt), and indium (0.7kt). The content of these three metals in ores that derive $20 \%$ or more of their value from lead is 21 to 31 times higher. In other words, a small reduction in lead extraction could have a minor impact on the availability of other resources, as long as only the most leadrich deposits are affected. However, if the profitability of extracting deposits with $\mathrm{Pb} \geq 20 \%$ of value was reduced, the consequences for availability of other metals would increase. Silver, zinc, and the zinc by-products indium and germanium would be particularly heavily affected.

\section{Production of Platinum-Group Elements}

Most PGEs are mined as the host metal (or rather group), and the greater part of reserves and resources are in deposits where PGEs are the host (Mudd et al. 2018). By-products from primary PGE mines include silver, nickel, copper, and gold. About $2 \%$ of primary nickel supply is a platinum byproduct (Nassar et al. 2015) but PGEs, particularly palladium, are also produced as a nickel by-product. This can be seen in the data on the share of revenues that PGE mines make from different metals (see Fig. 6).

Mines that obtain $\geq 50 \%$ of their revenues from PGEs supply a low share of other metals' total production. Nickel is the most important by-product by economic value, but PGE-rich mines only represent $2 \%$ of global primary nickel production. In the larger group, where mines obtain $\geq 20 \%$ of their revenue from PGEs, nickel-rich mines are present that instead produce PGEs as a by-product. In other words, lower PGE demand would primarily affect supply of the different PGEs, as nickel mines exist that produce PGEs as by-products. However, mines that extract PGEs produce different compositions of the respective PGEs compared to nickel mines. Platinum and palladium make up almost $90 \%$ of the PGE market by value (Cowley 2019). A decreased demand that reduced primary supply of these two metals would also reduce supply of rhodium, ruthenium, and iridium, as these three metals are primarily produced in PGE mines and not as by-products in nickel mines.

\section{Discussion}

\section{Uncertainties with Estimating Future Stocks, Potential Flows, and Recovered Flows}

The size of future stocks and flows are uncertain and have been disputed for long due to diverging assumptions on, e.g. 
Table 1 Summary of host resources for which demand may diminish as a result of reduced use of fossil fuels; by-products directly affected; and co-products for which supply could be reduced indirectly. The

\begin{tabular}{|c|c|c|}
\hline Host resource & By-product & Co-product \\
\hline \multicolumn{3}{|l|}{ Fossil fuels } \\
\hline Natural gas & $\begin{array}{l}\text { Helium ( } 100 \% \text { of global supply) } \\
\text { Sulphur ( }>30 \% \text { of global supply) }\end{array}$ & \\
\hline Coal & $\begin{array}{l}\text { Germanium ( } 40 \% \text { of global supply) } \\
\text { Sulphur (minor share recovered today, unutilized potential) } \\
\text { Gallium and rare earths (currently not utilized) }\end{array}$ & \\
\hline Oil & $\begin{array}{l}\text { Sulphur ( }>30 \% \text { of global supply) } \\
\text { Vanadium (approx. } 10 \% \text { of global supply) }{ }^{\mathrm{a}}\end{array}$ & \\
\hline \multicolumn{3}{|l|}{ Metals } \\
\hline Lead & $\begin{array}{l}\text { Bismuth ( } 54 \% \text { of global supply) } \\
\text { Antimony ( } 40 \% \text { of global supply) } \\
\text { Silver }(\leq 36.5 \% \text { of global supply) } \\
\text { Zinc }(1 \%)\end{array}$ & $\begin{array}{l}\text { Zinc (and zinc by- } \\
\text { products: Indium, } \\
\text { Germanium) } \\
\text { Silver }(\leq 36.5 \% \text { of global } \\
\text { supply) } \\
\text { Barium, Copper, \& Gold } \\
\text { (minor share) }\end{array}$ \\
\hline Platinum and palladium $^{\mathrm{c}}$ & $\begin{array}{l}\text { Rhodium, Ruthenium, Iridium, Osmium (close to } 100 \% \text { ) } \\
\text { Nickel ( } 2 \% \text { of global supply) }\end{array}$ & \\
\hline
\end{tabular}

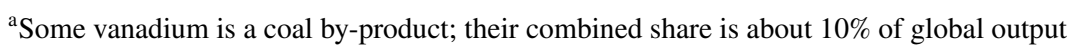

${ }^{\mathrm{b}}$ Lead-zinc-silver mines typically get most of their revenue from either zinc or lead. Silver can be either a co-product or by-product depending on ore grade and market price. The total share associated with $\mathrm{Pb}-\mathrm{Zn}$ is $36.5 \%$

${ }^{c}$ Platinum and palladium are either hosts or produced with other PGEs as by-products from nickel

future technological advancements. Lately, new issues have been identified that may constrain mining activities in the future, e.g. impacts of climate change (Northey et al. 2017; Odell et al. 2018) and increased risk of social instability due to environmental degradation (Lebre et al. 2020). This study has identified a new source of uncertainty, namely how mitigating climate change can reduce the use of host resources and thereby reduce primary supply of by-products.

Sections Resources Produced Jointly with Fossil Resources and Jointly Produced Elements from Elements Used in the Fossil Energy System identify that potential supply (i.e. flow) and availability (i.e. stock measured as reserves, or estimated ultimately recoverable resources) of by- and co-product elements could diminish if mining practices change due to carbon mitigation practices. It should be noted that Sect. Resources Produced Jointly with Fossil Resources only studies two fossil fuel supply scenarios and that many other trajectories are possible, for example if affordability of fossil fuels change (Garcia et al. 2020).

Supply potential, i.e. the total amount of recoverable byproducts contained in extracted minerals, is much higher than the current amount of primary product, because not all by-products are recovered. Estimates of current supply shares from different hosts are summarized in Table 1. Previous studies have argued that surplus flow provides flexibility to increase by-product supply from today's level without expanding host extraction, and that by-products are, therefore, not as scarce as they are commonly perceived to be (Frenzel et al. 2017; Jordan 2018). However, this argument is based on the assumption that primary host supplies do not decline. This study has found that the supply potential for some resources could decline as a result of mitigating climate change. One example is germanium, where $40 \%$ of current primary production is recovered from coal, but where coal accounts for nearly all (94\%) of the supply potential.

It is uncertain how much of the supply potential that it is feasible to recover, technically as well as economically. One example is Germanium that a lower cut-off grade increased the supply potential almost five times (see Fig. 2). This study did not consider to what extent the cut-off grade depends on prices and how price changes affect cut-off grades. This could be studied in more detail. Furthermore, this study assumed that the by-product content will not affect if a host is extracted or not. This has generally been the case with sulphur as an exemption (low sulphur deposits are preferred). Future research could analyse how and under what circumstances by-product content can affect profitability of extracting individual deposits and how this can affect byproduct supply potentials. For example, sour natural gas could become more valuable if sulphur becomes scarce.

Some host resources currently used in the fossil fuel supply chain can also be used in low-carbon energy systems. How reduced demand from the fossil fuel sector compares to increased demand from the energy transition is unclear. 
Table 2 List of elements at risk of reduced supply potential and/ or higher price as a result of phasing out fossil fuels; their relation to fossil fuels supply chains; examples of their enduse applications; and their status as critical according to the US and the EU

\begin{tabular}{|c|c|c|c|}
\hline Element(s) & Examples of applications ${ }^{\mathrm{a}}$ & $\begin{array}{l}\text { Critical } \\
\text { according to } \\
\mathrm{US}^{\mathrm{b}}\end{array}$ & $\begin{array}{l}\text { Critical } \\
\text { according to } \\
E U^{c}\end{array}$ \\
\hline Antimony & $\begin{array}{l}\text { Flame retardant, lead-acid batteries, armour-piercing bul- } \\
\text { lets, camouflage paint (IR reflector) }\end{array}$ & Yes & Yes \\
\hline Bismuth & Solders, alloy constituent, pharmaceuticals & Yes & Yes \\
\hline Gallium & Radar, mobile phones, LED, thin-film solar PV & Yes & Yes \\
\hline Germanium & Fibre optics, infrared lenses, thin-film solar PV & Yes & Yes \\
\hline Helium & MRI, lab equipment, arc welding & Yes & Yes \\
\hline Indium & Flat panel displays, LED, solar PV & Yes & Yes \\
\hline Rare earths & Permanent magnets (generators, engines), fibre optics & Yes & Yes \\
\hline Silver & Electronics, crystalline silicon solar PV, mirrors, jewellery & No & No \\
\hline Sulphur & Fertilizers, petroleum refining, ore processing & No & No \\
\hline Vanadium & Super alloys, high-strength steel, flow batteries & Yes & Yes \\
\hline Zinc & Coating steel (galvanizing) & No & No \\
\hline
\end{tabular}

Germanium and indium are zinc by-products. In turn, zinc and lead are co-products. This result in an indirect relation between lead and zinc by-products

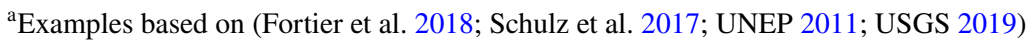

b(US_DoI 2018)

${ }^{c}($ EU 2020)
Platinum is a case in point. Platinum demand has declined recently in tandem with sales of internal combustion vehicles, which use platinum for exhaust catalysts. Demand for primary platinum is declining more rapidly than total demand, due to a high recycling rate of platinum catalysts and available stock in society. Platinum for fuel cell vehicles provides a possible new demand source, but battery electric vehicles have so far been more popular. The combinations of uncertain and time-divergent demand and high recycling rate of current use could be subject to more detailed studies in the future.

\section{Demand Increase for Identified By-Products and Available Substitutes}

The elements identified in this study as being at risk of reduced supply and/or price rises as a result of lower fossil fuel supply are used in a wide variety of applications (see Table 2). Previous studies have shown that demand for critical resources is expected to increase as renewable energy replaces fossil fuels (Arrobas et al. 2017; Watari et al. 2020). This study has found that several of these critical resources are at risk of reduced supply potential or price increases if fossil fuels are phased out, e.g. bismuth, germanium, gallium, indium, and vanadium. Bismuth can be used to increase solar-to-hydrogen conversion efficiency (Kim et al. 2015) and in catalysts to produce electrofuels from $\mathrm{CO}_{2}$ (Medina-Ramos et al. 2014). Germanium has optical properties and, similarly to gallium and indium, can be used in thin-film solar panels. Crystalline silicon photovoltaic cells do not use these metals but instead contain silver, which is also affected. That low-carbon energy transitions can simultaneously increase demand and reduce supply for critical resources has not been identified before. However, previous criticality research has highlighted that technological shifts that reduce host supply and increase by-product demand are more problematic that than those that only affect supply or demand (Nakamura et al. 2008). Future research could explore which other potential developments would reduce demand for host metals and how by-product supply would be affected, e.g. circular host material flows or degrowth.

Substitutes are often available to mitigate scarcity, but they have higher costs and/or lower performance. The inferiority of substitutes is one reason some elements are perceived as critical (Schrijvers et al. 2020). An element is considered a substitute for another if it can be used in the other element's place without modifying the technology. A more complex substitution method is using another technology (e.g. replacing permanent magnets with electromagnets) or set of technologies. Supply that is independent of fossil fuels can also provide a supply-side option for mitigating supply-demand imbalance. Some resources are used in applications where no substitute exists, e.g. helium for reaching very low temperatures and sulphur in fertilizers. These applications will require other responses than substitution, such as increased efficiency, stockholding programs to manage short-term disruptions, and, in the long-term, increased recycling rates.

Several of the identified elements are used in electrooptic devices, e.g. fibre optics, LED, lasers, solar photovoltaics, and flat panel displays. For solar photovoltaics, these elements are used in thin-film panels. Readily available 
element-level substitutes are rare, as several elements with similar properties are by-products, and their respective hosts' supplies will decline as fossil fuel supply declines. This is similar to the situation that previous research has identified for the PGE group, i.e. high element-for-element substitution within the group, but limited possibilities for substituting elements from outside the group (Nassar 2015). However, graphene and carbon nanomaterials can theoretically be used as substitutes in many electro-optic devices (Arvidsson and Sandén 2017). At the technological level, crystalline silicon solar photovoltaics are a readily available substitute for thin-film photovoltaics, but these use silver, for which supply is also at risk. Silver could in principle be substituted but at the cost of lower performance. New generations of solar PVs can be designed without the use of the identified at-risk elements (e.g. perovskites and dye-sensitized solar cells (Månberger and Stenqvist 2018)), but these are not yet commercialized and their outlook and market entrance remains uncertain.

Vanadium is not used in renewable energy production per se but can be used in stationary storage (vanadium redox flow batteries, VRFBs), which enables the integration of variable renewable power sources. VRFBs have not only lower energy density but also lower cost and longer lifespan than lithium-ion batteries. They also provide flexibility in design, since energy storage and installed power are functions of tank size and membrane, respectively. Stantec (2018) forecasts vanadium demand for VFRB to reach 40-80kt/y in 2030 (i.e. about 50-100\% of current primary supply) as a result of transitioning to variable renewable energy sources. ${ }^{5}$ The main use for vanadium currently is in alloys, and other metals, such as manganese and molybdenum, can to some extent be used instead or in combination (USGS 2019). This possibility, along with the fact that the vast majority of primary vanadium is produced independently of fossil fuels, indicates that the vanadium market is less exposed and sensitive to reduced supply from fossil fuels than the elements with electro-optic properties discussed above.

\section{Dynamic Assessments of Criticality and Geopolitics}

Elements are not critical in themselves, and history has shown that what is perceived as critical differs between actors and changes over time (Vikström 2016). All but three elements included in this study are categorized as critical by the USA (US_DoI 2018) and the EU (EU 2020). Sulphur is not classified as critical but this perception may change

\footnotetext{
${ }^{5}$ Stantec (2018) assumed stationary storage to reach $300 \mathrm{GWh}$ of which vanadium flow batteries make up $114 \mathrm{GWh}$ of installed capacity and have and energy density between $25-42 \mathrm{Wh} / \mathrm{l}$ and $81.51 \mathrm{~g}$ vanadium/l.
}

somewhat if fossil fuel use declines, since one of its major use is for macronutrient in fertilizers for which no substitute exists. Other supply sources exists but their geographical origin can differ from current fossil sources. New international trade flows and dependencies could thus develop.

Import dependence is one factor contributing to perceptions of criticality. The high geographical concentration of mineral reserves, refineries, and manufactures in few countries is by some seen as a cause of concern for import dependent countries, see e.g. (Smith Stegen 2015). The geographical distribution of fossil resources differs from the distribution of renewable energy resources and from the minerals used to build renewable energy infrastructure (Månberger and Johansson 2019; Overland et al. 2019). As a result, the transition to sustainable energy does not only affect the environment; it also has far-reaching implications for geopolitics and governance (Lee et al. 2020).

It is unclear how the geographical distribution of byproduct supply might be affected by the reduced use of fossil fuels. In some cases, it is possible for mining operations to respond to relative price changes by targeting ores within the deposit that contain a higher share of a co- or by-product and a lower share of the host (Farrow and Krautkraemer 1989). This supply response does not fundamentally alter the source of the supply. However, in other cases, entire ore deposits may become economical or uneconomical to mine, which would alter where supply comes from. Antimony, currently partly recovered from lead, provides a case in point. China holds about one third of global antimony reserves (USGS 2019). A majority of it is pure stibnite $\left(\mathrm{Sb}_{2} \mathrm{~S}_{3}\right)$, and some deposits have sufficiently high average antimony content to enable primary antimony mining (Jiada 1993). These sources could to some extent compensate for a reduction in supply recovered from lead, but China's dominant position as supplier could increase further, as only a few highgrade ore deposits of sufficient size to enable mining have been identified in other countries (Seal et al. 2017). Future research could study whether and how the geographical distribution of supply for other by-products could be affected, using the geographical distribution of reserves with high byproduct ore grades. Methodological inspiration can be found in the literature on the geographic distribution of "unburnable" fossil fuels (McGlade and Ekins 2014, 2015). Such studies would be of relevance to the geopolitics of energy transitions, insofar as transition would create relative winners and losers depending on distribution of resource endowments and alter current dependencies (Vakulchuk et al. 2020). That literature has, so far, focused on direct changes in resource demand (e.g. fossil fuels and hydropower) and overlooked indirect effects originating from changed use of non-fuel minerals. 


\section{Conclusions}

Previous research has shown that low-carbon energy transitions can increase scarcity of critical elements used in technologies to convert or store energy because of demand increase. This study shows that low-carbon energy transitions can also increase scarcity for elements that are (i) produced jointly with a resource that is mainly used within the fossil fuel supply chain, and (ii) recovered from fossil fuels when they are extracted, refined, or combusted.

Different options exist to mitigate the contracting supply potential of critical elements, including substituting with other elements; increasing the recovery rate to capture a larger share of the supply potential; and production from sources independent of fossil fuels. In general, recycling rates are low for the identified elements and the existing stock in society embedded in products that have reached their end of life is an additional supply source. These options' potential to mitigate increased resource scarcity differs for different elements, and future studies would be required to assess these in more detail.

This study identifies a group of four elements (indium, germanium, gallium, and to a lesser extent antimony) that are used for their electro-optical properties and that are problematic to substitute because each of these elements' main substitutes is found within the group. Previous studies have forecast that a low-carbon energy transition will increase demand for several of these elements because they are used in some solar PVs. Resource scarcity could, thus, increase because demand would increase at the same time as supply potential decreased. The problem is greatest for by-products that express dissipative losses in their lifecycles.

The main finding of this study points to a crucial policy trade-off that has so far been overlooked: it can be more difficult to meet low-carbon energy systems' demands for critical raw materials if fossil fuel use declines. This finding has theoretical implications as it illustrates the need to study supply chains of jointly produced resources as systems, rather than focusing only on individual resources. Further studies are warranted to explore other developments that may also reduce primary host supply potential such as circular economy.

Supplementary Information The online version contains supplementary material available at https://doi.org/10.1007/s41247-021-00088-5.

Acknowledgements This publication is a deliverable of MISTRA GEOPOLITICS, which is funded by the MISTRA - The Swedish Foundation for Strategic Environmental Research.

Funding Open access funding provided by Lund University.

\section{Declarations}

Conflict of interest The author declares no competing interests.

Open Access This article is licensed under a Creative Commons Attribution 4.0 International License, which permits use, sharing, adaptation, distribution and reproduction in any medium or format, as long as you give appropriate credit to the original author(s) and the source, provide a link to the Creative Commons licence, and indicate if changes were made. The images or other third party material in this article are included in the article's Creative Commons licence, unless indicated otherwise in a credit line to the material. If material is not included in the article's Creative Commons licence and your intended use is not permitted by statutory regulation or exceeds the permitted use, you will need to obtain permission directly from the copyright holder. To view a copy of this licence, visit http://creativecommons.org/licenses/by/4.0/.

\section{References}

Anderson CD (2019) Antimony production and commodites. In: Dunne RC, Kawatra SK, Young CA (eds) SME mineral processing \& extractive metallurgy handbook. society for mining, metallurgy, and exploration. Engelwood.

Anderson ST (2017) Economics, helium, and the U.S. federal helium reserve: summary and outlook. Nat Resour Res 27:455-477. https://doi.org/10.1007/s11053-017-9359-y

Arrobas DLP, Hund KL, Mccormick MS, Ningthoujam J, Drexhage JR (2017) The growing role of minerals and metals for a low carbon future. World Bank Group, Washington DC

Arvidsson R, Sandén BA (2017) Carbon nanomaterials as potential substitutes for scarce metals. J Clean Prod 156:253-261. https:// doi.org/10.1016/j.jclepro.2017.04.048

Bonel KA (2005) Barytes: mineral profile. British Geological Survey, Nottingham

Campbell GA (1985) The role of co-products in stabilizing the metal mining industry. Resour Policy 11:267-274. https://doi.org/10. 1016/0301-4207(85)90044-3

Church C, Crawford A (2018) Green conflict minerals: the fuels of conflict in the transition to a low-carbon economy. International Institute for Sustainable Development (IISD), Winnipeg

Clarke R, Clare R (2012) Helium from the air: the backstop. In: Nuttall WJ, Clarke R, Glowacki B (eds) The future of helium as a natural resource. Routledge, Oxon, pp 119-133

Cowley A (2019) PGM market report. Johnson Matthey, London

Danabalan D (2017) On the hunt for helium, physicsworld. IOP Publishing, https://physicsworld.com/a/on-the-hunt-for-helium/.

Edison (2017) Helium - macro view. Edison Investment Research, London

Elshkaki A, Graedel TE (2015) Solar cell metals and their hosts: a tale of oversupply and undersupply. Appl Energy 158:167-177. https://doi.org/10.1016/j.apenergy.2015.08.066

EU (2020) Critical raw materials resilience: charting a path towards greater security and sustainability. European Commission, Brussels

Farrow S, Krautkraemer JA (1989) Extraction at the intensive margin: metal supply and grade selection in response to anticipated and unanticipated price changes. Resources and Energy 11:121. https://doi.org/10.1016/0165-0572(89)90002-9

Ferg EE, Schuldt F, Schmidt J (2019) The challenges of a Li-ion starter lighting and ignition battery: a review from cradle to grave. J Power Sources 423:380-403. https://doi.org/10.1016/j. jpowsour.2019.03.063 
Fizaine F (2013) Byproduct production of minor metals: threat or opportunity for the development of clean technologies? the PV sector as an illustration. Resour Policy 38:373-383. https://doi. org/10.1016/j.resourpol.2013.05.002

Fortier SM, Nassar NT, Lederer GW, Brainard J, Gambogi J, McCullough EA (2018) Draft critical mineral list-summary of methodology and background information-U.S. Geological Survey technical input document in response to Secretarial Order No. 3359. U.S. Geological Survey, Reston.

Frenzel M, Ketris MP, Gutzmer J (2013) On the geological availability of germanium. Miner Deposita 49:471-486. https://doi. org/10.1007/s00126-013-0506-Z

Frenzel M, Ketris MP, Seifert T, Gutzmer J (2016) On the current and future availability of gallium. Resour Policy 47:38-50. https://doi.org/10.1016/j.resourpol.2015.11.005

Frenzel M, Mikolajczak C, Reuter MA, Gutzmer J (2017) Quantifying the relative availability of high-tech by-product metals - the cases of gallium, germanium and indium. Resour Policy 52:327-335. https://doi.org/10.1016/j.resourpol.2017.04.008

Fu X, Polli A, Olivetti E (2018) High-resolution insight into materials criticality: quantifying risk for by-product metals from primary production. J Ind Ecol 23:452-465. https://doi.org/10.1111/jiec. 12757

Garcia LE, Illig A, Schindler I (2020) Understanding oil cycle dynamics to design the future economy. Biophys Econom Sust. https:// doi.org/10.1007/s41247-020-00081-4

GEA (2012) Global energy assessment - toward a sustainable future. Cambridge University Press, Cambridge

Graedel TE, Reck BK (2016) Six years of criticality assessments: what have we learned so far? J Indust Ecol 20:692-699. https://doi.org/ $10.1111 /$ jiec. 12305

Gunn G (2014) Platinum-group metals. In: Gunn G (ed) Critical metals handbook. Wiley, Oxford, pp 284-311

IEA (2017) Energy technology perspectives. OECD, Paris

IEA (2020) World energy outlook. OECD, Paris

ILA (2012) Lead uses - statistics. International Lead Association, London

Imtiaz M, Rizwan MS, Xiong S, Li H, Ashraf M, Shahzad SM, Shahzad M, Rizwan M, Tu S (2015) Vanadium, recent advancements and research prospects: a review. Environ Int 80:79-88. https://doi.org/10.1016/j.envint.2015.03.018

Jiada W (1993) Antimony vein deposits of China. Ore Geol Rev 8:213232. https://doi.org/10.1016/0169-1368(93)90017-S

Jordan B (2018) Economics literature on joint production of minerals: a survey. Resour Policy 55:20-28. https://doi.org/10.1016/j.resou rpol.2017.10.002

Kim TW, Ping Y, Galli GA, Choi KS (2015) Simultaneous enhancements in photon absorption and charge transport of bismuth vanadate photoanodes for solar water splitting. Nat Commun 6:8769. https://doi.org/10.1038/ncomms9769

Klochko K (2016) Bismuth. In: USGS (ed) 2016 Minerals yearbook. U.S. Geological Survey, Reston.

Krenev VA, Drobot NF, Fomichev SV (2015) Bismuth: reserves, applications, and the world market. Theor Found Chem Eng 49:532535. https://doi.org/10.1134/s0040579515040120

Lebre E, Stringer M, Svobodova K, Owen JR, Kemp D, Cote C, Arratia-Solar A, Valenta RK (2020) The social and environmental complexities of extracting energy transition metals. Nat Commun 11:4823. https://doi.org/10.1038/s41467-020-18661-9

Lee J, Bazilian M, Sovacool B, Hund K, Jowitt SM, Nguyen TP, Månberger A, Kah M, Greene S, Galeazzi C, Awuah-Offei K, Moats M, Tilton J, Kukoda S (2020) Reviewing the material and metal security of low-carbon energy transitions. Renew Sustain Energy Rev 124:109789. https://doi.org/10.1016/j.rser.2020.109789

Lin R, Soong Y, Granite EJ (2018) Evaluation of trace elements in U.S. coals using the USGS COALQUAL database version 3.0. Part I: rare earth elements and yttrium (REY). Int J Coal Geol 192:1-13. https://doi.org/10.1016/j.coal.2018.04.004

Lin R, Soong Y, Granite EJ (2018) Evaluation of trace elements in U.S. coals using the USGS COALQUAL database version 3.0. Part II: non-REY critical elements. Int J Coal Geol 192:39-50. https:// doi.org/10.1016/j.coal.2018.04.005

Løvik AN, Restrepo E, Müller DB (2016) Byproduct metal availability constrained by dynamics of carrier metal cycle: the galliumaluminum example. Environ Sci Technol 50:8453-8461. https:// doi.org/10.1021/acs.est.6b02396

Maier RM (2015) Chapter 16 - biogeochemical cycling. In: Pepper IL, Gerba CP, Gentry TJ (eds) Environmental microbiology, 3rd edn. Academic Press, San Diego, pp 339-373

McGlade C, Ekins P (2014) Un-burnable oil: an examination of oil resource utilisation in a decarbonised energy system. Energy Policy 64:102-112. https://doi.org/10.1016/j.enpol.2013.09.042

McGlade C, Ekins P (2015) The geographical distribution of fossil fuels unused when limiting global warming to 2 degrees C. Nature 517:187-190. https://doi.org/10.1038/nature14016

Medina-Ramos J, DiMeglio JL, Rosenthal J (2014) Efficient reduction of $\mathrm{CO} 2$ to $\mathrm{CO}$ with high current density using in situ or ex situ prepared Bi-based materials. J Am Chem Soc 136:83618367. https://doi.org/10.1021/ja501923g

Mudd GM, Jowitt SM, Werner TT (2017) The world's by-product and critical metal resources part I: uncertainties, current reporting practices, implications and grounds for optimism. Ore Geol Rev 86:924-938. https://doi.org/10.1016/j.oregeorev.2016.05. 001

Mudd GM, Jowitt SM, Werner TT (2017) The world's lead-zinc mineral resources: scarcity, data, issues and opportunities. Ore Geol Rev 80:1160-1190. https://doi.org/10.1016/j.oregeorev.2016.08. 010

Mudd GM, Jowitt SM, Werner TT (2018) Global platinum group element resources, reserves and mining - a critical assessment. Sci Tot Environ 622-623:614-625. https://doi.org/10.1016/j.scitotenv. 2017.11.350

Månberger A, Johansson B (2019) The geopolitics of metals and metalloids used for the renewable energy transition. Energ Strat Rev 26:100394. https://doi.org/10.1016/j.esr.2019.100394

Månberger A, Stenqvist B (2018) Global metal flows in the renewable energy transition: exploring the effects of substitutes, technological mix and development. Energy Policy 119:226-241. https://doi. org/10.1016/j.enpol.2018.04.056

Nakamura S, Murakami S, Nakajima K, Nagasaka T (2008) Hybrid input-output approach to metal production and its application to the introduction of lead-free solders. Environ Sci Technol 42:3843-3848. https://doi.org/10.1021/es702647b

Nassar NT (2015) Limitations to elemental substitution as exemplified by the platinum-group metals. Green Chem 17:2226-2235. https://doi.org/10.1039/c4gc02197e

Nassar NT, Wilburn DR, Goonan TG (2016) Byproduct metal requirements for U.S. wind and solar photovoltaic electricity generation up to the year 2040 under various Clean Power Plan scenarios. Appl Energy 183:1209-1226. https://doi.org/10.1016/j.apenergy. 2016.08.062

Nassar T, Graedel TE, Harper EM (2015) By-product metals are technologically essential but have problematic supply. Sci Adv 1:e1400180. https://doi.org/10.1126/sciadv. 1400180

National_Research_Council (2000) The impact of selling the federal helium reserve. The National Academies Press, Washington, DC

Naumov AV (2007) Rhythms of rhenium. Russian Journal of NonFerrous Metals 48:418-423. https://doi.org/10.3103/s106782120 7060089

Northey SA, Mudd GM, Werner TT, Jowitt SM, Haque N, Yellishetty M, Weng Z (2017) The exposure of global base metal resources to 
water criticality, scarcity and climate change. Glob Environ Chang 44:109-124. https://doi.org/10.1016/j.gloenvcha.2017.04.004

Nuttall WJ, Clarke RH, Glowacki BA (2012) Stop squandering helium. Nature 485:573. https://doi.org/10.1038/485573a

Odell SD, Bebbington A, Frey KE (2018) Mining and climate change: a review and framework for analysis. Extractive Indust Soc 5:201214. https://doi.org/10.1016/j.exis.2017.12.004

Ojebuoboh FK (1992) Bismuth—production, properties, and applications. JOM 44:46-49. https://doi.org/10.1007/bf03222821

Olafsdottir AH, Sverdrup HU (2020) Assessing the past and future sustainability of global helium resources, extraction, supply and use, using the integrated assessment model WORLD7. Biophys Econom Sustain. https://doi.org/10.1007/s41247-020-00072-5

Oliver BM, Bradley JG, Farrar H (1984) Helium concentration in the Earth's lower atmosphere. Geochim Cosmochim Acta 48:17591767. https://doi.org/10.1016/0016-7037(84)90030-9

Onstad E (2019) Exclusive: Bosch goes for platinum-light fuel cells. Thomson Reuters, London

Overland I, Bazilian M, Ilimbek Uulu T, Vakulchuk R, Westphal K (2019) The GeGaLo index: geopolitical gains and losses after energy transition. Energ Strat Rev 26:100406. https://doi.org/10. 1016/j.esr.2019.100406

Rappold TA, Lackner KS (2010) Large scale disposal of waste sulfur: from sulfide fuels to sulfate sequestration. Energy 35:1368-1380. https://doi.org/10.1016/j.energy.2009.11.022

Redlinger M, Eggert R (2016) Volatility of by-product metal and mineral prices. Resour Policy 47:69-77. https://doi.org/10.1016/j. resourpol.2015.12.002

Reuter MA, Heiskanen K, Boin U, Van Schaik A, Verhoef E, Yang Y, Georgalli G (2005) The metrics of material and metal ecology, harmonizing the resource, technology and environmental cycles. Elsevier, Amsterdam

Schrijvers D, Hool A, Blengini GA, Chen W-Q, Dewulf J, Eggert R, van Ellen L, Gauss R, Goddin J, Habib K, Hagelüken C, Hirohata A, Hofmann-Amtenbrink M, Kosmol J, Le Gleuher M, Grohol M, Ku A, Lee M-H, Liu G, Nansai K, Nuss P, Peck D, Reller A, Sonnemann G, Tercero L, Thorenz A, Wäger PA (2020) A review of methods and data to determine raw material criticality. Resour Conserv Recycl 155:104617. https://doi.org/10.1016/j.resconrec. 2019.104617

Schulz KJ Jr, JHD II, RRS, Bradley DC (2017) Critical Mineral Resources of the United States-Economic and Environmental Geology and Prospects for Future Supply. U.S. Geological Survey, Reston.

Seal II RR, Schulz KJ, DeYoung Jr JH (2017) Antimony. In: Schulz KJ, DeYoung Jr JH, Seal II RR, Bradley DC (eds) Critical mineral resources of the United States-economic and environmental geology and prospects for future supply. U.S. Geological Survey, Reston.

Seredin VV, Dai S (2012) Coal deposits as potential alternative sources for lanthanides and yttrium. Int J Coal Geol 94:67-93. https://doi. org/10.1016/j.coal.2011.11.001

Smith Stegen K (2015) Heavy rare earths, permanent magnets, and renewable energies: an imminent crisis. Energy Policy 79:1-8. https://doi.org/10.1016/j.enpol.2014.12.015

Speight JG (2019) 8 - Gas cleaning processes. In: Speight JG (ed) Natural Gas, 2nd edn. Gulf Professional Publishing, Boston, pp 277-324

Sprecher B, Reemeyer L, Alonso E, Kuipers K, Graedel TE (2017) How "black swan" disruptions impact minor metals. Resour Policy 54:88-96. https://doi.org/10.1016/j.resourpol.2017.08.008

Stantec (2018) Bitumen beyond combustion - phase 2 report. Stantec Consulting Ltd., Edmonton

Sun Z, Cao H, Zhang X, Lin X, Zheng W, Cao G, Sun Y, Zhang Y (2017) Spent lead-acid battery recycling in China - a review and sustainable analyses on mass flow of lead. Waste Manage 64:190 201. https://doi.org/10.1016/j.wasman.2017.03.007

The_Barytes_Association (2019) Uses of Barytes. The Barytes Association, Brussels

Tokimatsu K, Höök M, McLellan B, Wachtmeister H, Murakami S, Yasuoka R, Nishio M (2018) Energy modeling approach to the global energy-mineral nexus: exploring metal requirements and the well-below $2{ }^{\circ} \mathrm{C}$ target with 100 percent renewable energy. Appl Energy 225:1158-1175. https://doi.org/10.1016/j.apenergy. 2018.05.047

UNEP (2011) Recycling rates of metals: a status report. United Nations Environment Programme, Paris

US_DoI, 2018. 83 FR 23295 - final list of critical minerals 2018. Department of the Interior, US.

USGS, 2019. Mineral commodity summaries 2019. U.S. Geological Survey, Reston.

USGS, 2020a. Mineral commodity summaries 2020. U.S. Geological Survey, Reston.

USGS, 2020b. Minerals yearbook: sulfur [Advance release]. U.S. Geological Survey, Reston.

Wagenfeld JG, Al-Ali K, Almheiri S, Slavens AF, Calvet N (2019) Sustainable applications utilizing sulfur, a by-product from oil and gas industry: a state-of-the-art review. Waste Manag 95:78-89. https://doi.org/10.1016/j.wasman.2019.06.002

Vakulchuk R, Overland I, Scholten D (2020) Renewable energy and geopolitics: a review. Renew Sustain Energy Rev 122:109547. https://doi.org/10.1016/j.rser.2019.109547

Valero A, Valero A, Calvo G, Ortego A (2018) Material bottlenecks in the future development of green technologies. Renew Sustain Energy Rev 93:178-200. https://doi.org/10.1016/j.rser.2018.05. 041

Watari T, McLellan BC, Giurco D, Dominish E, Yamasue E, Nansai K (2019) Total material requirement for the global energy transition to 2050: a focus on transport and electricity. Resour Conserv Recycl 148:91-103. https://doi.org/10.1016/j.resconrec.2019.05. 015

Watari T, Nansai K, Nakajima K (2020) Review of critical metal dynamics to 2050 for 48 elements. Resour Conserv Recycl 155:104669. https://doi.org/10.1016/j.resconrec.2019.104669

Werner TT, Mudd GM, Jowitt SM (2017) The world's by-product and critical metal resources part II: a method for quantifying the resources of rarely reported metals. Ore Geol Rev 80:658-675. https://doi.org/10.1016/j.oregeorev.2016.08.008

Werner TT, Mudd GM, Jowitt SM (2017) The world's by-product and critical metal resources part III: a global assessment of indium. Ore Geol Rev 86:939-956. https://doi.org/10.1016/j.oregeorev. 2017.01.015

Vikström H (2016) A scarce resource? the debate on metals in Sweden 1870-1918. The Extractive Industries and Society 3:772-781. https://doi.org/10.1016/j.exis.2016.03.009

Yakubov MR, Sinyashin KO, Abilova GR, Tazeeva EG, Milordov DV, Yakubova SG, Borisov DN, Gryaznov PI, Mironov NA, Borisova YY (2017) Differentiation of heavy oils according to the vanadium and nickel content in asphaltenes and resins. Pet Chem 57:849-854. https://doi.org/10.1134/s096554411710019x

Zartmann R, Wasserburg G, Reynolds J (1961) Helium, argon and carbon in some natural gases. J Geophys Sci 66:277-307. https:// doi.org/10.1029/JZ066i001p00277

Zhang W, Yang J, Wu X, Hu Y, Yu W, Wang J, Dong J, Li M, Liang S, Hu J, Kumar RV (2016) A critical review on secondary lead recycling technology and its prospect. Renew Sustain Energy Rev 61:108-122. https://doi.org/10.1016/j.rser.2016.03.046

Publisher's Note Springer Nature remains neutral with regard to jurisdictional claims in published maps and institutional affiliations. 